\title{
METAPHORS IN DIALOGUE: FEMINIST LITERARY CRITICS, TRANSLATORS AND WRITERS
}

\author{
Eleonora Federici \\ University of Calabria (Italy)
}

\begin{abstract}
This article seeks to investigate the changing perception of the term "translation" in feminist TS thanks to a continuous dialogue with other fields such as, feminist literary criticism, post-structuralism, postcolonial studies and cultural studies that have borrowed and utilised the notion of translation. "Translation" has become a "travelling concept" for feminist scholars who have utilized it in a metaphorical way for a feminist critique of language and ideology. The essay proposes a new approach to feminist translation studies from an interdisciplinary perspective that takes into account keyconcepts and figurative language in different feminisms in dialogue. Metaphors of translation and translators have influenced and have been influenced by other fields of research in a fruitful interaction among disciplines thanks to a convergence of the topics and issues at stake. A new rhetoric has been created for translation and translators, a rhetoric born from an interaction with other feminist theories that gave birth to an enriching dialogue among disparate women's voices.
\end{abstract}

\section{Resumen}

Este artículo intenta investigar la percepción del término "traducción" en la traducción feminista a través un diálogo continuo con otras disciplinas, como la crítica literaria feminista, el post-estructuralismo, los estudios poscoloniales, los estudios culturales que han utilizado la noción de traducción. La traducción se ha hecho un "travelling concept" para las estudiosas feministas que la han usado como metáfora para una crítica del lenguaje y de la ideología. Este artículo presenta un nuevo acercamiento a la traducción feminista desde una perspectiva interdisciplinar que considera los conceptos clave y el lenguaje figurativo en los diferentes feminismos en diálogo. Metáforas de la traducción y de los traductores han influido y han sido influidos por otras disciplinas gracias a una fructuosa interacción y a la convergencia de los temas. Una nueva retórica se ha creado para la traducción y los traductores, una retórica 
producida por la confluencia con otras teorías feministas en un dialogo entre voces femeninas.

Keywords: Feminist Translation. Feminist Literary Criticism. Women writers. Metaphors. Dialogue

Palabras clave: Traducción feminista. Crítica literaria feminista. Escritoras. Metáforas. Diálogo 


\section{Introduction}

As a living socio-ideological concrete thing, as heteroglot opinion, language, for the individual consciousness, lies on the borderline between oneself and the other. The word in language is half someone else's. It becomes one's own only when the speaker populates it with his own intention, his own accent, when he appropriates the word, adapting it to his own semantic and expressive intention. Prior to this moment of appropriation, the word does not exist in a neutral and impersonal language [...] but rather it exists in other people's mouths, in other people's contexts, serving other people's intentions: it is from there that one must take the word and make it one's own. (Bakhtin 1981: 293)

Bakhtin's quotation is useful for a consideration of translation as a process of syntactic/semantic change and as a practice of language shaping. Bakhtin never discussed translation but his notions are pertinent as a starting point for a discussion of this practice and the translator's role as a mediator between languages and cultures, a reading subject who decides and makes choices as a first interpreter of texts for the target reader. This essay starts from the premise of understanding translation in the Bakhtinian idea of dialogue and as a powerful act of communication. ${ }^{1}$ The notions of dialogue and communication in translation offer the opportunity to discuss not only the translator's role but also to outline a fruitful exchange among disciplines as a challenging starting point for recovering some convergences among feminist voices in diverse areas of research. Since it is not possible to trace all the points of contact among different disciplines, my attention here will be devoted to a study of the changing perception of the term "translation" in feminist TS thanks to a constant dialogue with other fields such as feminist literary criticism, poststructuralism, postcolonial studies and cultural studies that have borrowed and utilised the notion of translation, changing the perception we have today of the concept in TS. "Translation" has become a "travelling concept" not only

1. Various have been the studies on translation and communication. A very good example of interaction among disciplines on the subject is Mary Snell et al. (1997). 
in feminist research, ${ }^{2}$ but feminist scholars have utilized it in a metaphorical way useful for a feminist critique. I borrow the term from Mieke Bal's ${ }^{3}$ but extend it to the notion of "cultural concept" utilized for a critique of imperialist/patriarchal language, theories on identity and self-perception, debates on "situated knowledges" of scholars, translators and writers who propose a feminist critique. If we analyse TS from a feminist perspective today, we can see how concepts and metaphors on "translation" have moved from one discipline to another. Through appropriation, "translation" and reassessement of the term across various fields, metaphors about translation and translators have acquired new meanings which seem to be constantly and continuously renegotiated.

Feminist approaches very different from one another have used the term and its metaphorisations to discuss women's identity, writing, philosophical thought, and representation in media. Translation and its many "uses" have produced fruitful encounters of knowledge and, I believe, have ended up by influencing the perception of theories and practices of translation in feminist TS.

While feminist scholars in TS have dealt with the figure of the translator and its many metaphorisations in a new light, deconstructing the gendered metaphors associated with translation and creating new metaphorical figurations aiming at deconstructing the hierarchies between "feminized" translation activities and male authored texts and the writing task, scholars in feminist literary criticism, philosophy or postcolonial studies coming from very different socio-historical contexts have borrowed some of these metaphors and created new ones that could be forceful for a feminist agency.

It would be interesting, though we cannot deal with this issue in the present study for reasons of space, to see that while scholars have amplified the connotations of the notion "translation", translators have become the subject of novels such as Leila Abouleila's The Translator (1999), Eva Hoffman's Lost in Translation (1989), John Crowley's The Translator (2002). In these novels, just to cite a few examples, the protagonist embodies the difficulties of living in-between cultures and mediating linguistic differences. So translation has developed into a literary topic, a major theme of novels dealing with issues

2. Many have been the Postcolonial Studies that have dealt with this issue, for example, $G$. C. Spivak (1988), S. Bassnett \& H. Trivedi (1999).

3. Mieke Bal's volume Travelling Concepts in the Humanities: A Rough Guide (2002) has opened the debate on an emerging body of feminist studies that take into account how concepts travel in a range of disciplinary and international contexts. 
of cultural identity working as a metaphor for (lack of) communication, the clash between cultural differences and linguistic hybridity.

This essay seeks to offer a new approach to feminist translation studies from an interdisciplinary perspective that takes into account key-concepts in feminist literary criticism, feminist post-structuralism, the so-called third wave of feminist linguistics, post-colonial studies and cultural studies, because all these theories present challenging metaphors that have been used by different perspectives and have created a figurative language of feminism(s). It aims at demonstrating how metaphors of translation have influenced and have been influenced by other fields of research in a fruitful interaction among disciplines thanks to a convergence of the topics and issues at stake. A new rhetoric has been used for translation and translators, and it is born from an interaction with other feminist theories in a fertile dialogue among disparate women's voices.

\section{Translation as Dialogue}

If we look back at Bakhtin's quotation, we can extrapolate two other important factors: 1) translation can be regarded as an act of communication among human beings because to understand someone else means to translate his words and, at the same time, to communicate by translating our own thoughts into words; 2) translation changes according to the language users because interpretation involves a specificity in language use; any speaker is a translator of thoughts and an interpreter of other people's words and ideas. This speaker appropriates the words, makes them his own and creates his own language. Similarly, the translator interprets other people's words and reads a text, making it his own, permeating it with his accent and adapting it in the target language for the new reader. In so doing, the translator engages in an act of communication, conducts a linguistic and semiotic mediation, looking for what he believes to be the best option in his moulding of the text. A skilled translator is considered to able to juggle between words and worlds.

This craft and meticulous process of "selection, assemblage, structuration and fabrication - and even in some cases, of falsification, refusal of information, counterfeiting and the creation of secret codes" (Tymockzo and Gentzler 2002: xxi) has been clarified by feminist translators who, through the use of specific devices, have unveiled the process of "decoding" and "re-coding" meaning to new readers. Also non feminist scholars have dealt with this issue but feminist approaches to translation have made it plain and have proposed some techniques to be used. 
Another aspect that feminist translators have highlighted is that the translating subject is the site of many meanings revealed through the translating practice. They have shown how translators perform a mediating function between the source text/culture and the target text/culture. If translators have always known that a translation carries the voices not just of the original but also those of the translated text, feminist translators have demonstrated that translation can be considered as a heteroglossic, multivoiced practice. With their use of paratextual elements (prefaces, footnotes, glossaries) they have unveiled a dialogic relationship between author and translator, languages and texts. As well-known scholars have demonstrated (Simon 1996, von Flotow 1997, Santaemilia 2005) feminist translators opt for a practice of translation where the translator's traces in the text are visible and her agency acknowledged. The translating process is presented as a dialogical act in which author and translator are involved.

The idea of translation as a dialogue is certainly not only a feminist one. Just to cite one recent example of translation as a hermeneutic act, we can refer to Douglas Robinson, who wrote about the "dialogics of translation" where the translator is "in hermeneutical dialogue with the author" (Robinson 1991: xv). However, feminist scholars have reproduced their dialogue with the author/text on the page explaining to the reader their choices and making their process of translation clear. Barbara Godard, for example, directly alluded to Bakhtin's dialogism and defined feminist discourse as "dialogic, one-withinthe-other in the Bakhtinian sense of the polyphonic text" (Godard 1992: 88). We can add that even the famous definition of "heteroglossia" uniting the word "hetero" (the Greek for 'other') to "glossia" ('speech', 'language') seems to recall the notions of "difference" and "otherness" so much discussed in feminist studies. ${ }^{4}$ From this perspective, we can assert that Bakhtin's idea of the translational nature of language has been recovered by feminist scholars who interpret translation as a practice always on the "borders" between the self and the other and as an act of mediation.

\section{Metaphors of Translation}

A discussion of the translating practice and the agent of this process - the interpreter of the text-can start from the metaphors which have been related to this role and activity. As the Anglo-French writer Michèle Roberts

4. However, the issue of translation and otherness has been analysed also by non feminist scholars such as, for example, Theo Hermans (1996), who stresses how translated texts are plural and contain the "other" voice, the translator's voice. 
says, "metaphor can change one thing into another in the twinkling of an eye. Metaphor effects magical transformations [...] metaphor puts one thing close to another, collapses the distance between, lets one thing become another" (Roberts 1998: 145). Interestingly, the etymology of the term 'metaphor' from the Greek 'metapherein' means 'to carry over', like the Latin root 'transferre' from which the term translation derives: the two definitions are semantically and etymologically connected. In TS the metaphorical language utilized for translation has gone hand by hand with a metaphorical use of the term itself since the very beginning of this practice. The process of translation has been depicted through personification as if something inanimate were treated with human qualities and through similes where the comparison between translation and something else has been made explicit.

Metaphors for translation have always played a central role in translation studies (D'Hulst 1992, Hermans 1985) and an eminent scholar, Susan Bassnett (1999), outlined a diachronic lineage of metaphors from the eighteenth-century image of translation as a mirror for reality to John Dryden's comparison between the translator and the slave laboring in another man's plantation, a suggestion then perpetuated by Percy B. Shelley in his idea of translation as transplantation. Translators have been compared to travelers (Bassnett 1997), discoverers of intertextual maps (Federici 2007), nomads by obligation (Cronin 2003), rewriters busy in rewording (Orr 2003), nostalgic figures (Levine 1991) and to many other activities which have been connected to this practice. In one single essay, Geoffrey M. Green (2001) has outlined many metaphors for the translator: a creative artist, a puzzle solver, a musical arranger, an interpreter, an adapter, a performer, a spokesman, an advocate, an honest broker, a sort of magician of illusions. In so doing, he has perpetuated a common practice in translation theories, that is, finding connections that seemed to fit probably in order to dismantle the idea of translation as a secondary activity and to outline the difficulties of the translating task.

To use a metaphor in order to explain something in fact means to clarify and express the function of a term in a specific context, so metaphors of translations have changed through time according to perceptions of the translator's role and through space, that is, according to different contexts. The metaphorisation of translation, therefore, has been adapted to the time and setting of its production, following the two main aspects of translation: cultural transmission and interpretation. On the one hand, translators have been considered as mediators and bridge-builders, and, on the other, readers of a hermeneutical act. Clearly they are both. Writers or translators have utilized these metaphors not only to communicate their own ideas on the subject but 
also to express how they felt about doing so. Nicholas Round presented an interesting schema of etymological search about the metaphors for translation (Round 2005). The richness of metaphors of translation have made it, to borrow an expression from George Lakoff and Mark Johnson, one of the "metaphors we live by", a metaphor that has circulated among disciplines and acquired new meanings, an expanding "travelling concept".

The cultural force of translation has been primarily recognized by scholars in Postcolonial Studies, who have created new metaphors for translation, considered it as a forceful activity and a tool for colonization and have enriched the already full baggage of metaphors for translation/translators. Postcolonial theorists have invented new metaphors and outlined how, in postcolonial contexts, Europe was regarded as the "original" and the colonies as copies, translations of a European world they should replicate while acknowledging the "inferior" value of their own culture (Bassnett and Trivedi 1999, Cheyfitz 1991, Robinson 1997). They have highlighted the practice of translation as one of the ideological discourses of the colonizer, a metaphor of his power (Niranjana 1992) and created new metaphors of cannibalism (Vieira 1999) and re-appropriation. The metaphorisation of translation has been connected to the semantic field of ideological battleground (Bhabha 1994, Spivak 1992) and has become a common metaphor for power relations.

However, it is thanks to feminist scholars in TS that a new value has been added to the metaphorisation of the practice of translation and to the translator's role. Not only have they subverted and deconstructed some old metaphors but they also have suggested that translation is a way of writing/ reading/interpreting women's voices and producing new ones. Translation has become "transformance" (Godard 1990: 89), "a daring act" which requires courage and faith (Mezei 1998: 9), "a living process, ever beginning anew" (Ward Jouve 1991:28), "continuation of life-energy" (Bassnett 1980), a "new life blood" (Bassnett 1996), an act of skilled "manipulation" (Santaemilia 2005) explained through etymology:

The idea of 'manipulation' is inherent to the phenomenon of 'translation'. Both manipulare and translatare share a common lexical ground: an (artful) adaptation, change, transformation, transmission - it suits one's purpose or advantage. In a sense, the two terms are quasi synonyms, which are also associated with transgression, perversion or subversion. (Santaemilia 2005: 1)

If the metaphor of manipulation directly recalls the translator's agency and work on the text, as Michael Hanne (2006) has underlined, we can talk about assertive practices of feminist translators that include various metaphors: of territory (Bassnett 2005), "contact-zone" (Simon 1996), political acts and the 
production of hybrid texts (Alvarez and Vidal 1996), "archaeology and terrorism" (von Flotow 1997). Feminist translators have utilized semantic fields already exploited for translation (like that of transfusion or journey) but they have added a new dimension. This is important because metaphors about translation play a role shaping the way we understand this practice (cf. St. André 2010).

Hand in hand with the creation of new metaphors for translation, feminist scholars have begun a work of dismantling the gendered metaphors associated with the practice. They have highlighted how translation was considered as a secondary activity compared to writing and often visualized in feminine terms. As Barbara Godard has emphasized, "though traditionally a negative topos in translation 'difference' becomes a positive one in feminist translation" (Godard 1992: 92). In her famous essay on the "metaphorics of translation", Lori Chamberlain (1988) underlined the sexualization of translation through the issue of fidelity and the many metaphors connected to gender roles. Starting from the historical trope of the "femininity of translation" (les belles et infidèles) Sherry Simon (1996) proposed again the traditional masculine/feminine imagery of the translator/translation subverting it and recuperating lost voices of translatresses. The recovery of hidden voices of women translators has outlined the specificity of a feminine approach to the practice of translation since the very beginning of translatresses' work. Despite its status as a minor activity, translation has been acknowledged as a strong form of expression for women in recent centuries, permitting them to enter the world of letters and contribute to the intellectual life of the period, to become cultural agents of their time. The recovery of the work of the translatress has highlighted the pivotal importance of gender in the process of translation in a diachronic perspective revealing a lot about the social and cultural milieu where it has been produced. Historical studies on translation have gone hand in hand with the recovery of women authors and the precious research done by Anglo-American scholars working in literary studies who have underlined both the importance of the context and of the interpretative choices made by women.

\section{The Translator as Reader}

In Anglo-American criticism, writing as a woman is not a biological fact but an act of an individual who lives in a specific context and is embedded in linguistic and cultural maps. Feminist translation studies bear witness to these theories and their extensive use of metaphorical language. Discourses on/ of translation and discourses on/of/about women have been carried on by 
feminist literary criticism and have created a cross-breeding with TS. Elaine Showalter's "gynocriticism" (1979) is retraceable behind feminist voices in TS and so also is her idea of a "doubled voice discourse" (1981) which embodies the social, literary and cultural heritage. The same can be said for Annette Kolodny's response to Adrienne Rich's notion of "revision", that is to say, a "revisionary re-reading" (1975) which sounds implicit in the task of the feminist translator that has been perpetuated by Canadian scholars. All the metaphors created for a feminist reading of texts, the "resisting reader" (Fetterley 1978), "over-reading" and "arachnology" (Miller 1988), the "geography of identity" (Friedman 1996) and all the figurations connected to the theory of "situated knowledge" (Spivak 1985, Anzaldúa 1987, Spelman 1988, Trinh Min-Ha 1989, De Lauretis 1990, Haraway 1991) stand behind the work of feminist translators.

The dialogue engaged with the text in feminist approaches to TS has been influenced by the debate on the revision of the literary canon together with the notion of "rewriting" texts from a feminist perspective. The debate on the canon has not only brought about the search for lost women authors but also lost translatresses.

If Jonathan Culler (1982) talked about "reading as a woman" and other feminist scholars widely discussed women readers (Jacobus 1982, Moi 1985, Flint 1993), feminist translators have emphasized how, in the act of reading and interpreting a text, the discursive texture is amplified in the passage from one language into another. It is a texture to be composed, re-woven and re-ordered.

From this perspective, the feminist translator becomes the ideal reader, the "lector in fibula" so long theorized by Umberto Eco $(1979$; 1994) in her search for a complicity between authors, texts and readers. The translator/lector grasps the author's hints and unveils the intertextual references of the text, signaling her presence in the text in various ways: breaking the sentences, rewriting them, adding information with paratextual elements, paraphrasing the author's words. She explains her choices and informs the reader of her strategies of moulding the text. Her role as a reader and interpreter is clear.

The translator's signature becomes a metaphor too, because it stands as the acknowledgment of the translator's work and presence in the text, visualizing her agency. As in the discussion on women authors' signatures in translation, the (female) translator's signature is the sign of her difference, her subjectivity and her interpretative hermeneutic process. As for women's authoriality in writing, translating becomes an act of assertion, a practice which unveils personal reading and textual reproduction. After all, the signature is 
the sign of the writing subject, as Louky Bersianik affirmed as a writer (in de Lotbinière-Harwood 1991: 45).

Very interestingly, the notion of the translator as a reader/interpreter of text has been developed by Olga Castro (2009), who has suggested a new approach to translation which should take into account the complexities in translating the textual representation of women and men utilising feminist CDA (critical discourse analysis). In this way, the translator will be not only a reader and an interpreter of the text but a sort of "decoder" able to translate the discursive representation of gender. As Castro says, many are the possible lines of thought that can be developed on the subject of TS and feminism, and one of them, I believe, is possibly that of finding the key-metaphors that have been echoed among disciplines changing and amplifying the connotations of keyterms. The next section deals with one of the keyterms in feminist studies, the body and the metaphors of writing and translation that have been connected to this main locus/focus of feminist discourse.

\section{The Translator as Writer}

Women writers and translators speak in a highly metaphorical manner of language, desire and difference and multiplicity. Corporeality, identity and writing have been joined together in feminist literary criticism since the 70s. If, generally speaking, translation represents "difference", because it means to transfer a source text into a target text that will always bear the sign of a different language, culture and context of production, feminist translation highlights even more this "otherness", considering the gender difference that supposedly changes the reading and translation of a text. The notion of gender difference has been a central one in feminist literary criticism, both in the Anglo-American context and in the French and Italian contexts, even if considered from different perspectives. ${ }^{5}$

If the Anglo-American approach can be useful when connected to the idea of the translator as an interpreter, as we have anticipated in section 3, the socalled French Feminism can be interesting for a discussion on the metaphors related to the translator as a writer. French theorists such as Luce Irigaray, Julia Kristeva and Hèléne Cixous have proposed what has been defined as écriture féminine, a fundamentally and essentially "feminine writing". Language is a priority for these theorists, who believe that we need to be concerned with the

5. We have already cited some of the main theorists of the Anglo-American wave. Important for a development of the notion of "difference" have also been Italian philosophers such as Adriana Cavarero (1987) and Luisa Muraro (1991). 
deep structure of language where they locate women's position as the "Other". Influenced by Jacques Lacan's psychoanalytic theories and focusing on female subjectivity and the connections with the maternal, in their theories women's bodies work as a symbolic construct and a sign of passage between the maternal (semiotic) and the patriarchal (symbolic). ${ }^{6}$ The highly metaphorical language of French philosophers has also drawn upon the terms of translation. ${ }^{7}$ The female body has been seen as "translated" onto the page, Hélène Cixous has talked about the white ink of the maternal which translates femininity and creates a new language which totally subverts syntax and lexicon. Various metaphors have been utilized, like for example, the "Medusa's laugh" (Cixous 1975), a "newborn body" (Cixous and Clement 1986), "lips speaking together" (Irigaray 1980). French Feminism has debated on "Woman" as a universal construct, metaphorically speaking about the "Other", the "Mother", the "Medusa", to give just a few examples of the highly metaphorical language utilized by these writers. They have also discussed, even if not in a direct way, the issue of translation. For example, Hélène Cixous in Vivre l'Orange (1979) plays with two languages and offers to the reader a bilingual text in which the author translates the French text into English maintaining the syntactic structure of the first language and creating neologisms and wordplay. Here Cixous not only writes about the metaphor of translation or that of "being translated" but elaborates some issues about the use of languages and the translation of some of her main concepts into another language.

The impact of French Feminism in North-America has been widely discussed and so the difficulty in the translation of "untranslatable" terms like jouissance or écriture féminine. The term 'New French Feminism' itself was coined for the Anglo-American outsider to designate the body of feminist theory which emerged in France in the 70s and 80s in the wake of poststructuralism and Lacanian psychoanalysis, bringing together the three major scholars — Luce Irigaray, Julia Kristeva and Hélène Cixous- despite the many differences among them. In her essay on the reception of French Feminism in North America, Bina Freiwald (1991) stresses the consequences of translation of their works into the American market. Mis-translation and a simplification/"domestication" of these theories heavily bounded in the

6. The "translation" of terms from psychoanalysis and philosophy has been extensive. See for example Julia Kristeva (1984).

7. I use the term French theorists because they have always been recognized as the main exponents of French Feminism. However, it is important to keep in mind that they are hybrid voices of multicultural contexts. Irigaray is Belgian, Kristeva, Bulgarian and Cixous, Algerian, all of them speaking more than one language. 
French context of those years and unknown to the American reader have caused some misunderstanding and critical responses in the North American context, creating a sort of binary opposition among feminisms. The transmission of texts and culture and the risk of a selective translation which ends up in silencing the specificity of the different/"other"'s theoretical stance is a very important factor to take account of when discussing translation (cf. Simon 1996). The translations of French Feminist works in English have unveiled the differences both in linguistic expressions and ideological conceptualizations. When differences between social and cultural contexts are many, the translator should act as a mediator, providing an interpretative and explanatory apparatus (footnotes, glossaries, explanations around keywords), so that the density of the source text can be perceived by the target reader who can guess the complexity of this kind of writing while understanding it. Many metaphors and word-play have also been used to designate the differences between Anglo-American feminist criticism anchored to the historical context and women's lives, and French Feminism influenced by psychoanalysis and linguistics. For example, Mary Jacobus (1982) asserted, using two metaphors, that the main difference is in the French "textuality of sex" compared to the American "sexuality of text".

The metaphorical language of feminine creativity has been used also by feminist translators influenced by French Feminism especially in the Quebecois context. For example, the Canadian scholar Susanne de Lotbinière Harwood states in her famous volume Re-Belle et infidèle: la traduction comme pratique de reécriture au feminin/The Body Bilingual: Translation as Rewriting in the Feminine (1991): "I am a translation because I am a woman" (de Lotbinière Harwood 1991: 95), recalling both the French existentialist idea of femininity and all the gendered connotations of the act of translation. However, in her provocative study, as a feminist translator she emphasized a positive idea of translation as change, transformation, mediation as an essential part of women's subjectivity. Translation is for her a locus of creativity. The title itself of her work clarifies her intent: the French part immediately brings to mind l'écriture féminine and the works of French theorists so focused on the body, while the English part underlines how the woman's body has always been considered as the site of difference and the semiotic sign of gendered lives. This is not a silent body but a body that speaks "with a forked tongue" as the Anglo-French feminist scholar/translator Nicole Ward Jouve reminded us:

Translation is an activity by means of which the 'natural' bond 'meaninglanguage' can be transgressed. It is a state of continued suspension - [...] in Walter Benjamin's words, 'the post-maturation of the foreign speech, the 
birth throes of one's own speech'. The process, therefore, is eminently 'feminine'. When you translate, the absolute status of nouns, the 'Name-of-the Father', is shaken. Exchanges between words are no longer 'full', that is, guaranteed by the law of significance. Identities cease to be stable. You escape from definition, from the law which rules and partitions women, which prevents femininity from coming into being. Translation $=$ no man's land $=$ woman's land? (Ward Jouve 1991: 28)

Translation is perceived by Ward Jouve as a "feminine" process because translating is for women an act of writing the self. Similarly, for de Lotbinière Harwood, translation is here considered as a feminine activity, a form of rewriting. Both writers talk about a feminine writing, a poetics born of the fluidity of their body. From this perspective they stand as examples of what we could define as "re-écritures féminines". The association between women's bodies, writing and the language of the mother/the mother-tongue $e^{8}$ is thus reiterated in translation; the translator talks about a translating body, a "body lost in translation" (de Lotbinière Harwood 1991: 83). The body becomes the metaphor for the subject:

Un corps traduisant. À la fois corps lisant, corps écoutant et corps ré-écrivant, il circule sans arrêt dans le mots du texte à traduire, il parcourt les dictionnaires et l'intertexte, fouille son propre imaginaire, interroge l'auteure, se penche vers les lectrices... En mouvement perpètuel, le corps traduisant performe le passage entre le sens de départ à décoder et le sens d'arrivée à encoder, toujours en tenant compte du rapport d'adresse, de la relation à l'autre —comme sur une scène. (de Lobtinière 1991: 48)

It seems that translators influenced by French theories utilize some metaphors from these writers and write about translation in very metaphorical language. Yet from this last quotation we can extrapolate another metaphor often utilized for translation, translation as a performance, a mise en scène, an acting out of difference.

This idea of translation as performance, an old one in TS, has acquired a new meaning for feminist scholars. Luise von Flotow, for example, affirmed that "translation is always a representation, a performance of another author's work" (von Flotow 1999: 282). If this is an acceptable starting point for any translator, analysing Barbara Godard's translations and going beyond her notion of "transformance" von Flotow outlined how feminist translation practice leads to a reconstruction of meaning which changes the translated text:

8. I use both terms deliberately because the reference is to writing as connected to the feminine and the maternal language and mother tongue, meaning first language. 
translations perform what the source text does in the source culture. Such theory moves the text into a third dimension, the dimension of performance. It conceptualizes translation as a three-dimensional activity that not only operates between two languages but also performs the first language in the second language, bringing it to feminist life". (von Flotow 1997: 44)

As a matter of fact, feminist translators play with language considering it as a performance, regarding their practice of translation as a performative utterance and a battleground for a linguistic, cultural and gendered identity. It is a practice that aims at deconstructing the myths of objectivity and transparency in language. ${ }^{9}$ A feminist approach to translation gives the reader a critical perspective on the difference between the original and its translation. The "rewriting" of the text, thus, is carried on in the name of "feminist truths" which aim at the deconstruction of archetypal feminine images and gendered discourses.

If performance is part of translation, translators are certainly not conceived of as invisible presences in the target text, "shadows" echoing the author's words, but active agents in the process of cultural transmission. Moreover, they are agents who know that their acts are not neutral. In fact, echoing once again French Feminism, in particular Luce Irigaray's sentence "parler n'est jamais neutre", de Lotbinière-Harwood affirms that "traduire n'est jamais neutre" (1991: 27). In her text, de Lotbinière-Harwood deconstructs another main metaphor of translation, the idea of the "beautiful and unfaithful" and she does so playing with the words in French, "re-belles"/"rebels". Looking closely at this text, the reader sees that the French and English sections are not the same, and are not translations of each other; they interconnect, but they are different as if the content of one language could not be translated into the other. Similarly, Nicole Ward Jouve asserts that she can write prose in her mother tongue, French, but criticism only in her step-mother tongue, English, as if the two languages were connected to different selves and ways of writing. De Lotbinière's text on translation is subjective and emotional. She uses an autobiographical style that reinstates the authority of the personal register for the translator, giving content and positionality to the translator's voice. In a very similar way, Ward Jouve's text is an analysis of her own writing and translating through an autobiographical route which the reader is invited to follow.

9. However, non feminist theorists in TS also have acknowledged the performative nature of translation. See for example, Douglas Robinson who talks about "Performative linguistics", where translation is a use of language and the decision-making process, a performative act. 
These texts are hybrid texts filled with words that bring to mind many connotations, especially if we gather all the intertextual allusions to other feminist texts, and they are written in a highly experimental style. They echo not only the texts of French theorists as we have already underlined, but also those experimental feminist novels of the 70s which have been the subject of feminist studies in TS, books filled not only with neologisms, but also new syntactical and grammatical constructions. De Lotbinière-Harwood exemplifies her work as a translator, linking it with her role as a reader and writer and to her gender, Ward Jouve demonstrates how her work as an intellectual is marked by the idea of translation itself, utilized in a metaphorical way for a life in between languages, a "translated self". The next section will take account of this notion, which has become a metaphor in itself defining the position and identity of many intellectuals born and bred in-between several cultures.

\section{Writers living in translation}

Already in 1989 an entire issue of Tessera was dedicated to "La traduction féminine/Translating Women", to the relationship between writing and translation. One of the main scholars in the field, Sherry Simon, considers translation a "fluid production of meaning similar to other kinds of writing" (Simon 1996: 12) and talks about a writing project in which both writer and translator participate. However, the connection between writing and translation is certainly not born with the discussion of translation and gender, ${ }^{10}$ many writers in fact, have compared their work to that of translators and have connected the notions of identity and translation in a metaphorical way. Salman Rushdie affirms we are all "translated beings living in translated words" (1991: 13), ${ }^{11}$ José Saramago asserts that "to write is to translate [...] we transfer what we see or feel into a conventional code of symbols" (Saramago 1997: 85), Michèle Roberts explains in detail how she feels "translated" between the French and English cultural worlds through metaphors of crossing, moving and displacing (Roberts 1998). Eva Hoffman talks about loss in translation and a "life in a new language" where translation is a "therapy" that offers "instruments and the vocabulary of self-control" (Hoffman 1989: 273-274). Translingualism (Kellman 2000) also has been considered as a form of translation because

10. Recently Susan Bassnett and Peter Bush edited an interesting volume on The Translator as Writer (2006).

11. In Postcolonial Studies this is a very common issue and the metaphor of translation is recurrent. 
the use of different languages, code-switching and code-mixing, linguistic interferences and calques can be considered as forms of a "translational writing" where authors resort to more than one language to build their narrative world.

If there are many examples of writing seen as translation, we would like now to refer to a specific writer who has also been taken into consideration by de Lotbinière-Harwood in her work. The metaphor of the "borderlands", a term highly connotated by the Chicana writer Gloria Anzaldúa, has been used and adapted for feminist translation: "from these spaces on the 'borderlands' between underlying text and translated text, a translator can address readers in her own voice, supply information about the author, comment on the text and on her translation strategies, credit her sources and suggest further reading" (de Lotbinière-Harwood 1991: 157). The ambiguous polysemic term "borderland"(cf. Zaccaria 2006) however, has been utilised as a metaphor for translation, connecting it to the positive idea of border-crossing, bridge, land of passage, together with the conception of language as plural, coral, but here it has gained a specific meaning related to the "location" of the subject.

Anzaldúa's Borderlands/La Frontera is first of all a negotiation within the problematic limits of language, the liminal space of writing conceived as a "crossing over", as a "translation" between languages and cultures. Language is identity: "ethnic identity is twin skin to linguistic identity" (Anzaldúa 1987: 81). A multitude of languages, English, Spanish, Mexican Spanish, TexMex, Chicano Spanish, Pachuco (caló, the secret language of the barrio) are inserted in the text to visualize the Mestizaje, the in-between space of Chicanas. Anzaldúa's work demonstrates how the translation from one language to another can be considered as a positive result of contamination: "There, at the juncture of cultures, languages cross-pollinate and are revitalized" (Anzaldúa 1987: 20), reformulating the metaphor of "new life" and revitalization presented by some TS scholars. Chicano language is "per se an interlanguage, a contact language spoken in a contact zone: a language in incessant metamorphosis, in constant translation" (Zaccaria2006: 62). Anzaldúa uses the metaphor of "translation" in order to express her idea of language, identity and writing, which for her is an act of translation (cf. Godayol 2000). As in de Lotbinière-Harwood's text - a very different text for historical and cultural context but, however, interesting for the centrality of these issues- the bilingual choice makes visible the linguistic and cultural hybridity of the writer embedded in different cultures. The writer (Anzaldúa), the translator (de Lotbinière-Harwood), the scholar (Hélène Cixous), all create bilingual texts using a metaphorical language of women's bodies and translations. 


\section{Concluding remarks}

The acts of writing, reading and translating become intertwining routes where it is possible to retrace women's subjectivity, identity and creativity. Dialogues among disciplines have led to the movement of "travelling concepts" from one field to the other. Feminist approaches to TS have been enriched by keyterms and discussions in literary studies, Postcolonial Studies, Cultural Studies and linguistics.

The creativity of feminist scholars has created echoes of many metaphors. Metaphors of translations have been used to deconstruct established patterns of cultural, social and gendered ideologies and, at the same time, to portray new figurations of feminist agency in various fields, creative and critical writing and translation. Debating on women's role as writers, intellectuals, translators, scholars have created new challenging metaphors which envision the necessity to re-think women's writing as connected to the body, identity, social and cultural "location".

The term translation itself has been used in a metaphorical way in order to visualize a state of linguistic and cultural hybridity to the point that it has probably lost its figurative power but has acquired new operational values. Are these metaphors still working in feminist acts of reading, interpreting and translating nowadays or have they become a catachresis?

Probably, after this widening of significance, the term translation cannot be used as a fixed and stable concept but rather as a dynamic, flexible and open cultural notion. We know now that the translator's task is not a mere transcoding of linguistic, cultural and social codes, but that it starts from the premise that translation is a discursive act transmitting values. So while rethinking literariness in regard to the unity of the text and reading the original from her own location and perspective, the translator fulfils the translating process well aware of her cultural role and agency in this process.

After decades of Deconstruction, Poststructuralism, Postcolonialism, Cultural Studies and Gender Studies we know how to be critical subjects; we are aware of our "location" and of our impossible naivety as readers or translators. However, translators have to mediate - acknowledging their location and culture, they must create a readable text for the new reader. Feminist translators have demonstrated that the act of translation can be carried on and explained making visible the translator's choices and adopting strategies as if there was a dialogue among them, the translated author and the new reader. So, if we have to find a metaphor for translation maybe we can choose that of a triangle where translator, author and reader are closely interconnected each to the other in the search for meaning. 


\section{References}

ABOUleila, Leila. (1999) The Translator. New York: Black Cat.

Álvarez, Román \& Carmen África Vidal Claramonte (eds.) (1996) Translation, Power, Subversion. Clevedon: Multilingual Matters.

AnZALdÚA, Gloria. (1987) Borderlands/La frontera: The New Mestiza. San Francisco: Aunt Lute Book Company.

BAKHTIN, Mikhail. (1981) The Dialogic Imagination Four Essays. M. Holquist (ed.). Austin: University of Texas Press.

BAL, Mieke. (2002) Travelling Concepts in the Humanities: A Rough Guide. Toronto: Toronto University Press.

BASSNETT, Susan. (1996) "The Meek or the Mighty: Reappraising the Role of the Translator". In: Alvarez, R. \& C. A. Vidal (eds.) Translation, Power, Subversion. Clevedon: Multilingual Matters, pp. 10-24.

BASSNETT, Susan. (1997) "Observations on Translation and Literature". In: Translating Literature, Cambridge: The English Association. pp. 11-13.

BASSNETT, Susan. (1999) "Metaphorically Translating". Textus Quaderni di studi semiotici, gennaio-aprile, special issue, La traduzione. G. Franci \& S. Nergaard (eds.) pp. 35-45.

BASSNETT, Susan \& Harish Trivedi (eds.) (1999) Postcolonial Translation: Theory and Practice. London: Routledge.

BAssnett, Susan. (2005) "Translation, Gender and Otherness". Perspectives. Studies in Translatology, 13:2. pp. 83-90.

BHABHA, Homi. (1994) The Location of Culture. New York: Routledge.

CASTRO, Olga. (2009) "(Re)Examining Horizons in Feminist Translation Studies: Towards a Third Wave?" MonTI 1. pp. 59-86.

CAVArero, Adriana. (1987) "Per una teoria della differenza sessuale" In: VVAA. Diotima. Il pensiero della differenza sessuale. Milano: La Tartaruga.

Chamberlain, Lori. (2004) "Gender and the Metaphorics of Translation." In: Venuti, L. (ed) The Translation Studies Reader. Routledge: New York. pp. 306-321.

CHEYFITZ, Eric. (1991) The Poetics of Imperialism: Translation and Colonization from The Tempest to Tarzan. Oxford: Oxford University Press.

Cixous, Hélène. (1975) "Le rire de la Méduse". LAarc 61. pp. 39-54

Cixous, Hélène. (1979) Vivre l'orange. Paris: Editions des femmes.

Cixous, Hélène and Catherine Clement. (1986) The Newly Born Woman. Trad. B. King. Manchester: Manchester University Press.

Cronin, Michael. (2003) Translation and Globalization. London: Routledge.

Crowley, John (2002) The Translator. New York: Harper Collins.

Culler, Jonathan. (1982) On Deconstruction: Theory and Criticism after Structuralism. Ithaca: Cornell University Press. 
D’Hulst, Lieven. (1992) "Sur le rôle des métaphores en traductologie contemporaine". Target 4:1. pp. 33-51.

De Lauretis, Teresa (1990) "Eccentric Subjects: Feminist Theory and Historical Consciousness". Feminist Studies 16:1. pp. 115-50.

ECO, Umberto. (1979) Lector in Fabula. Milano: Bompiani.

FEDERICI, Eleonora. (2007) "The Translator's Intertextual Baggage". Forum for Modern Language Studies 43: 2. pp. 147-60.

FETterley, Judith. (1978) The Resisting Reader: A Feminist Approach to American Fiction. Bloomington: Indiana University Press.

Flotow, Luise von. (1997) Translation and Gender: Translating in the 'Era of Feminism'. Manchester: St Jerome Press.

Flotow, Luise von (1999) "Genders and the Translated Text: Developments in 'Transformance"'. Textus XII. pp. 275-87.

FreiWALD, Bina. (1991) "The Problem of Trans-lation: Reading French Feminism". TTR 4:2. pp. 55-68.

FriEDMAN, Susan Stanford (1996) "Beyond Gynocriticism and Gynesis: the Geographics of Identity and the Future of Feminist Criticism." Tulsa Studies in Women's Literature, 15:1. pp. 13-40.

GODARD, Barbara. (1990) "Theorizing Feminist Discourse/Translation" In: Bassnett, S. \& A. Lefevere (eds.) Translation, History, Culture. London: Routledge. pp. 87-95.

GODAYOL, Pilar. (2000) Espais de frontera. Gènere i traducció. Vic: Eumo Editorial.

GrEEN, Geoffrey M. (2001) Thinking Through Translation. Athens: University of Georgia Press.

HANNE, Michael (2006) "Metaphors for the Translator". In: Bassnett, S. \& P. Bush (eds.) The Translator as Writer. London: Continuum. pp. 208-24.

HaraWAY, Donna. (1991) "A Cyborg Manifesto: Science, Technology, and Socialist-Feminism in the Late Twentieth Century" In: Simians, Cyborgs and Women: The Reinvention of Nature. New York: Routledge. pp.149-181.

Hermans, Theo. (1985) "Images of Translation. Metaphors and Imagery in the Renaissance Discourse on Translation”. In: Hermans, T. (ed.) The Manipulation of Literature. London: Croom. pp. 103-36.

Hermans, Theo. "Translation's Other" (1996), An Inaugural Lecture, University College London, 19 March 1996 [available online at http://eprints.ucl. ac.uk/198/. (Accessed on 9.11.2010)

Hoffman, Eva. (1989) Lost in Translation: A Life in a New Language. London: Minerva.

IRIGARAY, Luce. (1980) "When our Lips Speak Together". Signs 6. pp. 69-79.

JACOBus, Mary (1982) "Is There a Woman in this Text?". New Literary History, vol. 14. pp. 117-141. 
Jouve, Nicole Ward. (1991) White Woman Speaks with Forked Tongue. Criticism as Autobiography. London: Routledge.

Kellman, Steve G. (2000) The Translingual Imagination. Lincon \& London: University of Nebraska Press.

Kolodny, Annette. (1980) "A Map for Re-Reading: or Gender and the Interpretation of Literary Texts". New Literary History 11. pp. 451-67.

KRISTEVA, Julia. (1984) Revolution in Poetic Language. New York: Columbia University Press.

LAKOFF, George \& Mark Johnson. (1980) Metaphors we Live By. Chicago: Chicago University Press.

LEVInE, Suzanne Jill. (1991) The Subversive Scribe. Translating Latin American Fiction. Saint Paul, Minn.: Graywolf Press.

MEZEI, Kathy. (1998) "Traverse". Tessera 6, Special issue La traduction au féminin/ Translating Women. pp. 9-10.

Miller, Nancy. (1988) Subject to Change: Reading Feminist Writing. New York: Columbia University Press.

MoI, Toril. (1985) Sexual/Textual Politics. London: Routledge.

Muraro LuISA. (1991) Lordine simbolico della madre. Roma: Editori Riuniti.

NiRANJAnA, Tejaswini (1992) Siting Translation: History, Post-Structuralism and the Colonial Context. Berkeley: University of California Press.

OrR, Mary. (2003) Intertextuality. Debates and Contexts. Cambridge: Cambridge University Press.

RicH, Adrienne. (1987) "Notes Toward a Politics of Location”. In: Blood, Bread and Poetry: Selected Prose 1979-1985. London: Virago.

RoberTS, Michèle. (1998) Food, Sex and God: on Inspiration and Writing. London: Virago.

RoBinson, Douglas. (1991) The Translator's Turn. Baltimore: John Hopkins University Press.

Robinson, Douglas. (1997) Translation and Empire: Postcolonial Theories Explained. Manchester: St Jerome Press.

Round, Nicholas. (2005) "Translation and its Metaphors: the (N+1) Wise Men and the Elephant". Skase. Journal of Translation and Interpretation 1. pp. 47-69.

RUSHDIE, Salman. (1991) Imaginary Homelands. Essays and Criticism 1981-1991. London: Granta.

Santaemilia, José, (ed.) (2005). Gender, Sex and Translation: the Manipulation of Identities. Manchester: St Jerome.

Saramago, José. (1997) "To Write is toTranslate" In: Orero, Pilar \& Juan Sager (eds.) The Translator's Dialogue. Amsterdam: John Benjamins. pp. 85-85.

SHOWALTER, Elaine. (1979) "Toward a Feminist Poetics". In: Women's Writing and Writing About Women. London: Croom Helm. 
SHOWALTER, Elaine. (1981) "Feminist Criticism in the Wilderness". Critical Inquiry 8, pp. 243-70.

Simon, Sherry. (1996) Gender in Translation: Cultural Identity and the Politics of Transmission. London: Routledge.

Snell Hornby, Mary; Zusana Jettmarova \& Klaus Kaindl (eds.) (1997) Translation as Intercultural Communication. Amsterdam: John Benjamins.

SPELman, Elizabeth V. (1988) Inessential Woman: Problem of Exclusion in Feminist Thought. London: the Women's Press.

SPIVAK, G. C. (1985) "Three Women's Texts and a Critique of Imperialism." Critical Inquiry 12:1. pp. 243-61.

SPIVAK, G. C. (1988) In Other Worlds. Essays in Cultural Politics. New York: Routledge.

SPIVAK, G.C. (1992) "The Politics of Translation". In: Barrett, M. \& A. Phillips (eds.) Destabilizing Theory: Contemporary Feminist Debates. Cambridge: Polity Press. pp.397-416.

ST. ANDRÉ, James. (2010) Thinking through Translation with Metaphors. Manchester: St Jerome.

Trinh, Minh-Ha T. (1989) Woman, Native, Other: Writing Postcoloniality and Feminism. Bloomington: Indiana University Press.

TYMOCZKO, Maria \& Edwin Gentzler (eds.) (2002) "Introduction" In: Translation and Power. Amherst: University of Massachussetts Press. pp. xi-xxviii.

VIEIRA, Else Ribeiro Pires. (1999) "Liberating Calibans. Readings of Antropofagia and Haroldo de Campos' Poetics of Transcreation." In: Bassnett, S. \& H. Trivedi (eds.) 1999. Postcolonial Translation: Theory and Practice. London: Routledge. pp.95-113.

ZaCCARIA, Paola (2006) "Translating Borders, Performing Trans-nationalism". Human Architecture. Journal of the Sociology of Self-Knowledge IV. pp. 57-70. 